DOI: $10.11649 /$ abs.2019.008

\title{
Danguolè Mikulèniené
}

Institute of the Lithuanian Language

Vilnius

lki@lki.lt

https://orcid.org/0000-0001-7781-7236

\section{Aušra Pacevičiūtè}

Vilnius University, Kaunas Faculty

Kaunas

info@knf.vu.lt

\section{Language shift: The case of the Žeimiai area in the Kaunas-Jonava region}

Considering that traditional dialectology defines dialect as a system, researchers have often focused on the central part of a dialect area rather than its periphery, where phenomena that are not typical of a dialect in question may be found. As the usual practice would be to strictly keep to the defined limits of a dialectal unit, they tended to be ignored rather than studied and described.

Until the end of the twentieth century, thorough investigation only covered peripheral Lithuanian subdialects or those left outside the country's borders and destined to wither due to new political and sociocultural circumstances and the intensive influence of Slavic languages. The Kaunas-Jonava region, although located in the middle of Lithuania, can also be considered a peripheral dialect zone, as it is an area where the Lithuanian and Polish languages coexist. 


\section{Introduction}

As a result of application of the principles of multidimensional dialectology in Lithuania, researchers began investigating the ongoing processes of convergence and divergence of linguistic variants in a more comprehensive manner, not only analysing the linguistic characteristics of a local variation, but also looking into the language environment (or language landscape) and the attitude of the local populace (especially the young generation) towards their linguistic homeland. In this regard, unique are the recent studies of Polish subdialects in Lithuania presented in a collective monograph published in 2016 (Mikulènienè, Leskauskaité, Ragaišiené, Geržotaite, \& Birgelienè, 2016). Consequently, cases when several local language variations interact and compete with one another in the same geographical area can no longer be overlooked. Besides, it has been noted that only the rising prestige of a language (and thus of its local variation) will promote its evolution and development (Williams, 2005, p. 137). These are one of the first comprehensive studies of this kind conducted in Lithuania.

The subject of the study: The Kaunas-Jonava region, one where several local variations of both Lithuanian and Polish have been historically used (see Fig. 1), is a unique part of the territory of the Lithuanian language. Studies of this area have so far been fragmented: dialectologists have investigated and described local Lithuanian and Polish subdialects separately (e.g. Karaś, 2002; Zielińska, 2002; Zinkevičius, 1966, 2006). A systemic approach to the linguistic situation in Lithuania was applied within the framework of a European Union project (Geržotaité, 2012, 2017; Mikulènienè \& Rutkowska, 2013; Rutkovska, 2014, et al.). ${ }^{1}$

At least three variations can be identified in this area: (1) a historical traditional variation of the Polish language, i.e. Local Polish; (2) at least one of several local variations of Lithuanian that preserve the features of the Western Higher Lithuanian subdialect (with some characteristics of the Western Higher Lithuanian subdialect of the Kaunas region preserved in the southern part of the area around Muniškess, Babtai, Panevėžiukas, etc., and a variation similar to the Western Higher Lithuanian subdialect of the Šiauliai region, spoken to the southeast of the said area), i.e. Dialectal Lithuanian; (3) a particular strain of standard (or rather non-dialectal) Lithuanian that has been taught in schools since the 1910s or 1920s (Pacevičiūte, 2018 , p. 8), i.e. Standard Lithuanian. The local populace do not come under a direct

${ }^{1}$ The project was conducted by the Institute of the Lithuanian Language in 2010-2013; the aim was to monitor the locations included in the Atlas of the Lithuanian Language and to record the current status of dialects in Lithuania. More information is available at http://www.tarmes.lt/images/Veikla/ SANTRAUKA_0112.pdf; see also Mikulènienė \& Meiliūnaitė, 2014. 


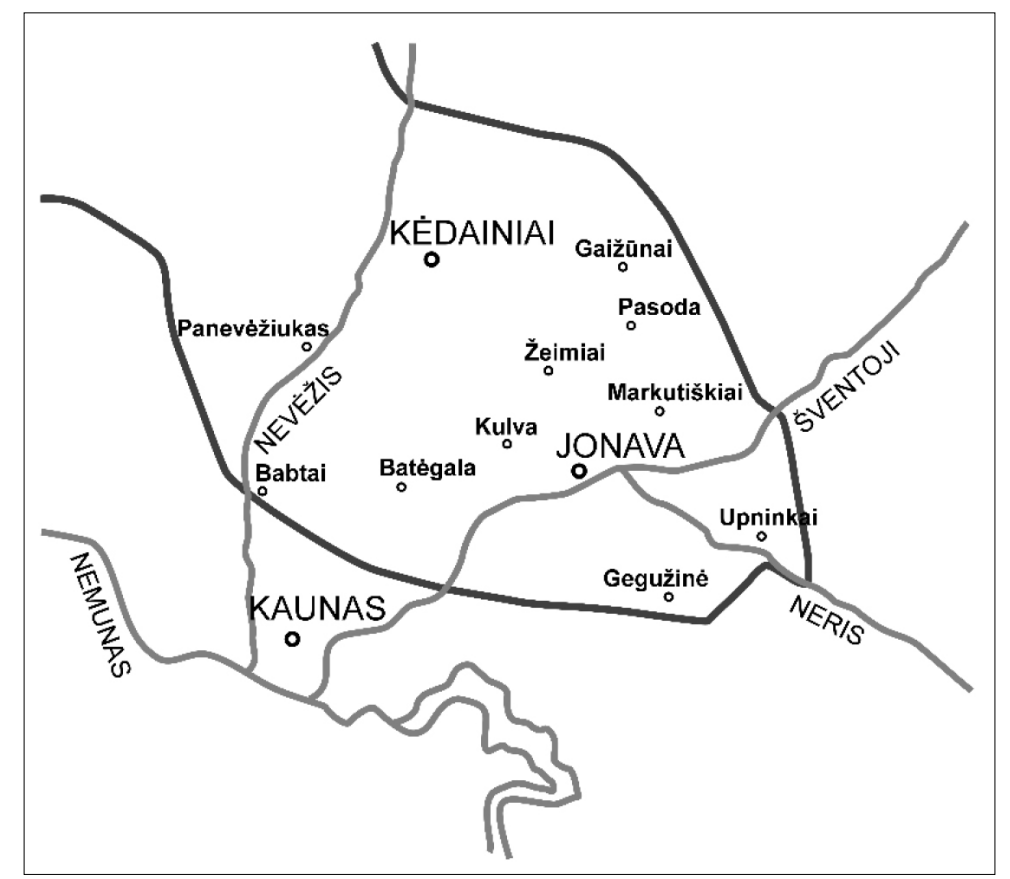

Fig. 1: The Kaunas-Jonava region (Geržotaitè, 2012, p. 157)

influence of Standard Polish language as it ceased to be the language of instruction in schools around Žeimiai in 1919 (Kviklys, 1991, p. 159).

As it is today, the entire Kaunas-Jonava region is dominated by the Lithuanian language. As Polish does not have any use in public domains at all, this type of usage can be defined as regressive (minimal) bilingualism (Rutkovska, 2014, p. 221).

The aim of the study: This article aims to discuss the competitiveness of the early twenty-first century local language variations around Žeimiai in the Kaunas-Jonava region from the sociogeolinguistic perspective.

Study material: The study was conducted in the Žeimiai area in 2015-2017; it involved interviews with 21 members of three generations of one family ( $15 \mathrm{fe}$ males and 6 males aged 19 to 95). ${ }^{2}$ The choice of informants was based not only on their place of origin (only those from the Žeimiai area were eligible), but also on the ability of at least one member of each generation to speak variations of Lithuanian and Polish subdialects (Pacevičiūtè, 2018, pp. 30-32). The audio material (over

2 The informants are related to Aušra Pacevičiūtè, one of the authors of this article. 
20 hours in total) recorded during interviews allowed the researchers to conduct a detailed analysis of the characteristics of local language variations.

Research methods and stages: The description and analysis of collected material involved: (1) analysis of the degree of viability of language variations used in the area considering the sociocultural networks of Žeimiai town; (2) description of the linguistic landscape of the region; (3) description of the linguistic behaviour and attitudes towards local variations on the basis of informants' replies in the sociolinguistic survey; (4) analysis of salient phonetic features of the informants' speech that best describe the local language variation in use.

The collected and processed material allowed the researchers to investigate the competitiveness of local language variations in this region, identifying ones that have greater demand with representatives of different generations compared to others (cf. Inoue, 1997, p. 41).

\section{Sociocultural networks and linguistic landscape}

Sociocultural networks of the population of Žeimiai were analysed following an approach that had already been applied in the case of other locations in Lithuania (Čepaitiené, 2016; Leskauskaite, 2016). The same set of indicators - school, hospital, shops, post office, church, library - was applied here to examine the viability of the area (see Fig. 2).

The density of the sociocultural networks of Žeimiai can be assessed as medium, as the town has a population of under a thousand. Local residents know one another quite well, although some of them have moved there from other regions (see Pacevičiūte, 2018, pp. 25-26). The level of viability is determined on the basis of the intensity of functions of sociocultural networks; we may say that Žeimiai is a rather viable place because, in addition to the institutions mentioned above, the town has a rather active cultural and communal life, with a number of festivals and commemorative events taking place (Pacevičiūte, 2018, p. 26).

Figure 2 shows that the degree of isolation of Žeimiai is average: local residents are able to take care of their daily business without leaving the town, which has a primary school, a dispensary, a shop, a post office, a church and a library. However, secondary school students have to make a daily commute to Jonava. Also, thorough medical tests or shopping for specialty items would require a trip to larger urban centres, mainly Jonava and Kaunas.

The town is a borough seat, which means that residents of the surrounding area take their business to Žeimiai post office and school. Žeimiai church is a place of worship both for people from the villages around and from Jonava or other more 


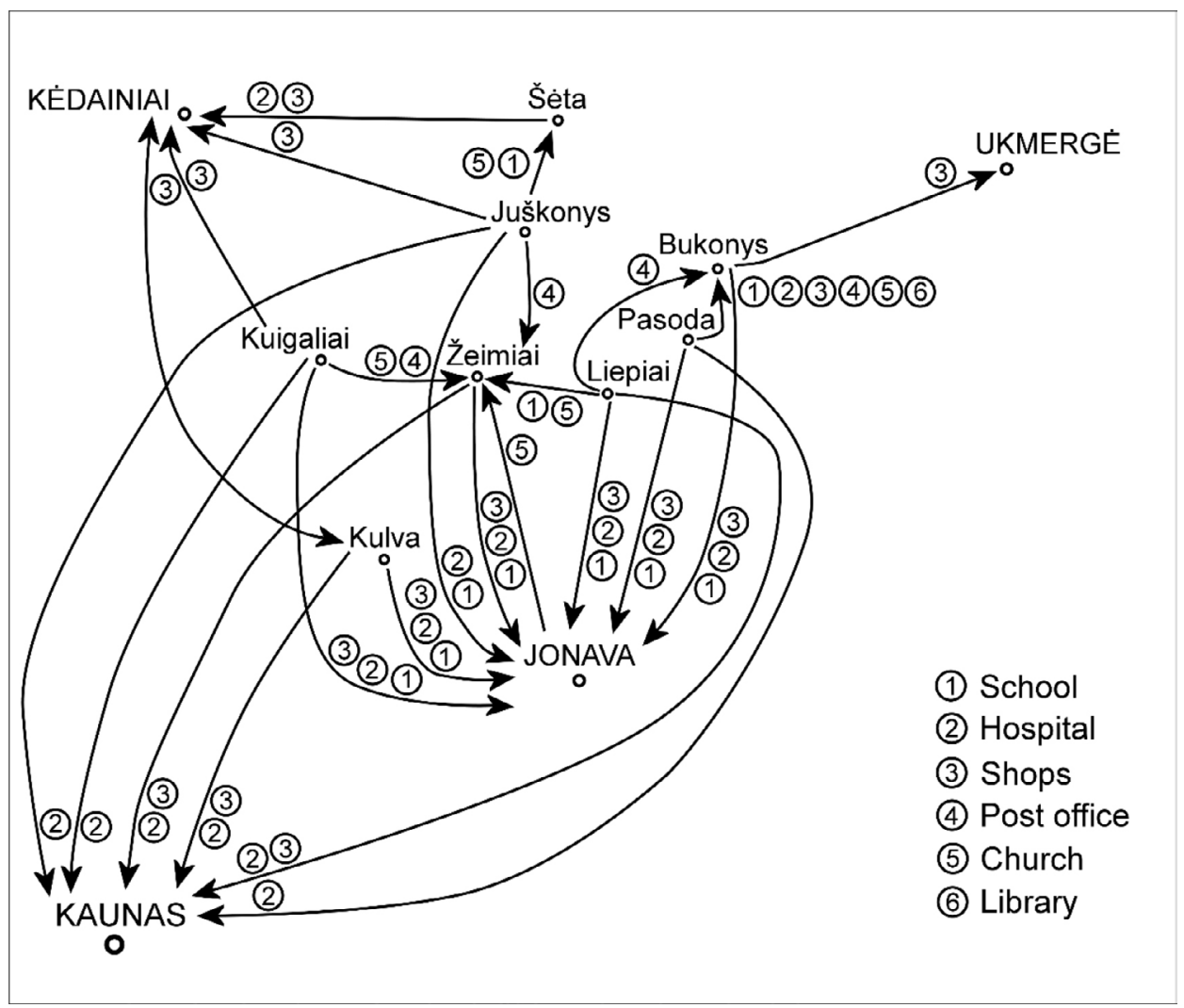

Fig. 2: Sociocultural networks in the Žeimiai area

remote towns. Therefore, we may say that the sociocultural networks of Žeimiai are open, because contacts with other language communities are quite frequent (Pacevičiūtè, 2018, pp. 25-26).

Studies of the linguistic landscape point to the prevalence of non-dialectal (standard) Lithuanian. The fact that Polish was once used in public domains in the area is currently evident only on gravestones. In the course of field studies, 35 legible gravestone inscriptions in Polish were identified in Žeimiai cemetery, the oldest of them dating back to 1897 and the most recent - to 2004. A total of 14 such gravestones were identified in Žeimiai churchyard, the oldest of them dating back to 1864 and the most recent - to 1912 (see Figs. 3 and 4).

Some inscriptions carved on the headstones contain errors, as can be seen in Figure 4, where the word westchnienie is missing the letter $c$, and the letter used for 

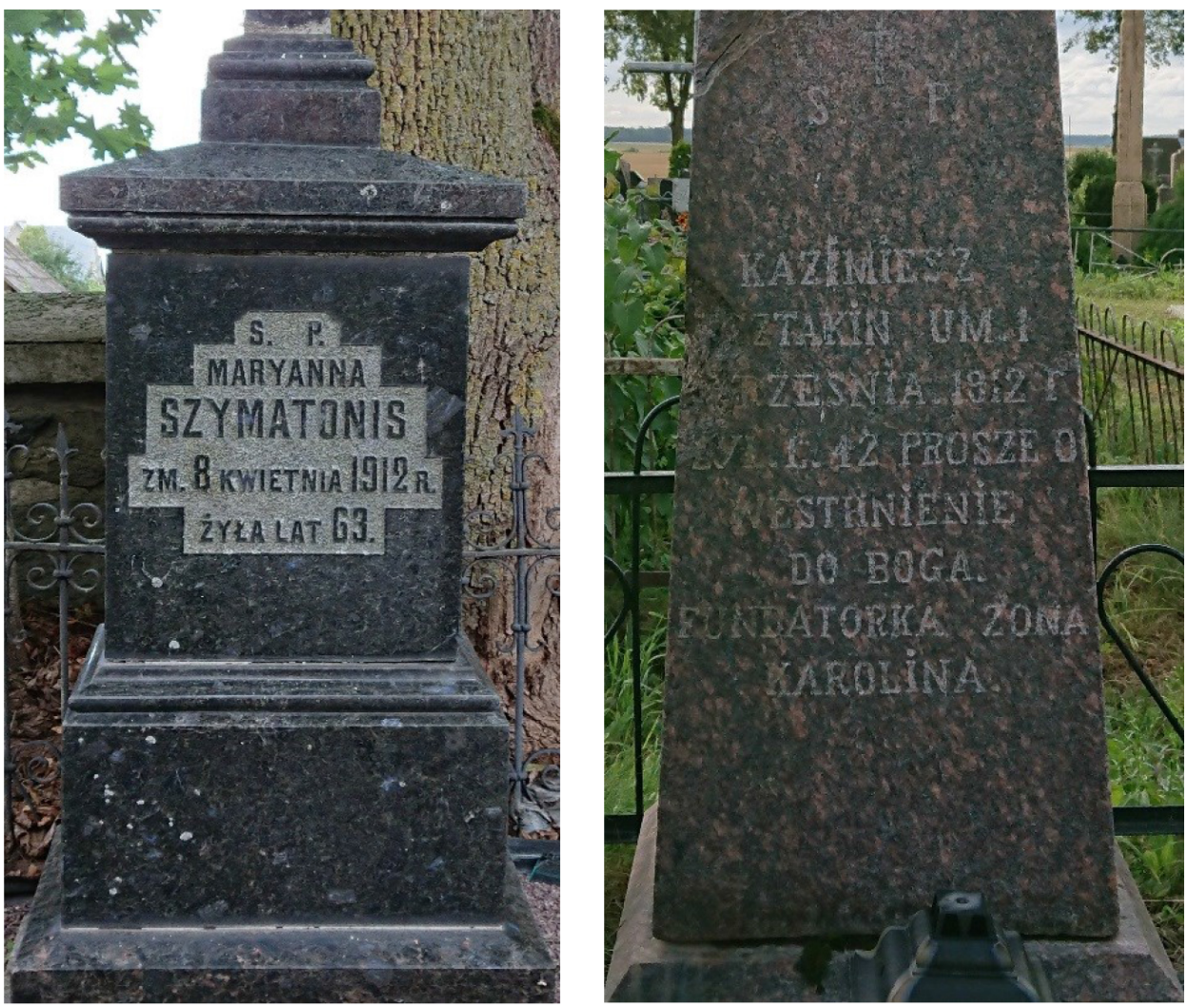

Fig. 3-4: Gravestone inscriptions in Žeimiai cemetery and churchyard. Photos by Aušra Pacevičiūtè (2018)

the nasal vowel in the word prosze is $e$ instead of $e$. It can be assumed that similar errors are also the case in other inscriptions, which suggests that the command of written Polish in the area was not very good.

Public information is made available to local residents in Lithuanian, the official language of the country. In the case of the notice in Figure 5, however, the spelling errors made by the author (or authors) suggest that the language they used (or still use) at home was (or still is) not Lithuanian. This is evident in the failure to differentiate between the Lithuanian vowels $\dot{e}$ and $e$ : demesiui (=demesiui), the confusion of short and long vowels: apsisükineti (=apsisukinèti), and the inconsistent use of letters for nasal vowels: sąnkasu (= sankasu). 


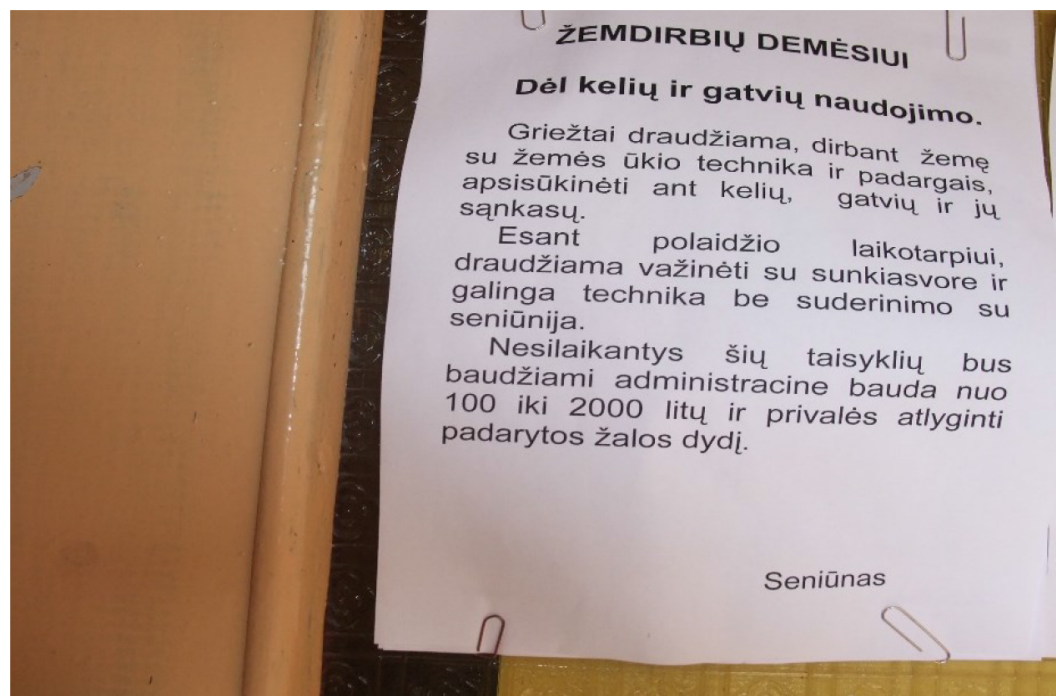

Fig. 5: Kulva borough announcement. Photo by Danguolè Mikulènienė (2011)

\section{Survey results}

The informants replied to a set of questions drafted for the project called "Modern Geolinguistic Research in Lithuania: The Optimisation of Network Points and the Interactive Dissemination of Dialectal Information." ${ }^{3}$ The survey revealed some patterns concerning the level of education and residence profile of informants from different generations. Their replies will be used in comparative research in the future.

The informants from the oldest generation (6 females and 1 male aged 74-95) have spent most of their lives in the region; many of them only have primary or secondary education. In all cases their native tongue is the local dialect of Polish, which is why they say they use it whenever possible. For instance, the parents of informant B1M (aged 78) were of different ethnicities (her mother was Polish), but the only language spoken at home was the Polish subdialect; it was the only language she used until she was seven, when she spent six months in hospital, where she learned some Lithuanian. She would speak Polish with her parents, sister, and maternal and paternal grandparents. She says she speaks Lithuanian with her chil-

\footnotetext{
3 See note 1 above.
} 
dren, grandchildren and younger people who cannot speak Polish, as well as with strangers. When asked about her skills in particular languages, she said she could understand, speak, read and write in Lithuanian, and she could understand and speak Russian and Polish. She speaks her native Polish subdialect, but she has never been taught to read or write in standard Polish (Pacevičiūtè, 2018, pp. 32-33).

The respondents admit that the Polish subdialect only has use with the oldest age group, and that they have to speak Lithuanian as often as not. The second most common variation is dialectal (local) Lithuanian. The old generation also speaks Russian.

All respondents from the middle generation (5 females and 2 males aged 47-61) have tertiary education and tend to travel more often. They can speak the local Polish subdialect, because most of their parents and grandparents could not speak Lithuanian. For instance, informant B2M (aged 48) used to speak Polish with her mother and maternal grandmother; she speaks dialectal Lithuanian with the rest of her family and considers Lithuanian her mother tongue. She is aware that the Polish subdialect she speaks is different from standard Polish. Although she can speak and understand Polish, her skills in that language are limited (Pacevičiūte, 2018, pp. 39-40). It is worth noting that the respondents from the middle age group use non-dialectal Lithuanian (which they refer to as 'standard language') more often than the oldest generation. Generally, they have the best level of skills in the three language variations and, in addition, they also have a relatively good command of Russian.

Some respondents from the youngest generation ( 3 males and 4 females aged 19-38) plan to study or have already enrolled into university; they travel a lot. Only two of them said they could speak the local Polish subdialect. Unlike members of the older age groups, the young people say they can speak English better than Russian. As a rule, the young informants choose to use the standard (or rather non-dialectal) variation of the Lithuanian language, although they opt for the local dialectal variation in unofficial situations.

A summary of survey questions about the use of language variations indicates that typically there are two (or even three) variations to choose from: the local Polish subdialect and the dialectal Lithuanian variation; the local dialectal variation and the standard (that is, non-dialectal) Lithuanian language (see the table below). The local Polish subdialect is still in use among the three generations. Of course, the scope of its use has greatly diminished.

We may say that this analysis of linguistic attitudes of the respondents and their use of language across different generations reveals some distinct changes in the use of particular language variations, with the standard (that is, non-dialectal) language often used in official settings, and the dialectal (local) variation of the Lithuanian language thriving in public domains. 
Table 1: Competitiveness of language variations (Pacevičiūtè, 2018, pp. 49-50) ${ }^{4}$

\begin{tabular}{|c|c|c|c|}
\hline Variation to speak & Oldest generation & Middle generation & Youngest generation \\
\hline In the family & $\begin{array}{c}\text { Local Polish 7 } \\
\text { Dialectal Lithuanian 5 }\end{array}$ & $\begin{array}{c}\text { Dialectal Lithuanian 7 } \\
\text { Local Polish 5 }\end{array}$ & Dialectal Lithuanian 6 \\
\hline Thinking & $\begin{array}{c}\text { Local Polish 6 } \\
\text { Dialectal Lithuanian 6 }\end{array}$ & Dialectal Lithuanian 7 & Dialectal Lithuanian 7 \\
\hline At the market & $\begin{array}{c}\text { Local Polish 4 } \\
\text { Dialectal Lithuanian 7 }\end{array}$ & Dialectal Lithuanian 7 & $\begin{array}{l}\text { Standard Lithuanian 4 } \\
\text { Dialectal Lithuanian 3 }\end{array}$ \\
\hline In public institutions & $\begin{array}{c}\text { Dialectal Lithuanian 5 } \\
\text { Standard Lithuanian 2 }\end{array}$ & $\begin{array}{l}\text { Dialectal Lithuanian 5 } \\
\text { Standard Lithuanian 2 }\end{array}$ & $\begin{array}{l}\text { Standard Lithuanian 6 } \\
\text { Dialectal Lithuanian 2 }\end{array}$ \\
\hline At meetings, assem- \\
blies & $\begin{array}{c}\text { Dialectal Lithuanian 5 } \\
\text { Standard Lithuanian 2 }\end{array}$ & $\begin{array}{l}\text { Dialectal Lithuanian 6 } \\
\text { Standard Lithuanian 2 }\end{array}$ & $\begin{array}{l}\text { Standard Lithuanian 4 } \\
\text { Dialectal Lithuanian 4 }\end{array}$ \\
\hline With friends & $\begin{array}{c}\text { Local Polish 7 } \\
\text { Dialectal Lithuanian 6 }\end{array}$ & $\begin{array}{c}\text { Dialectal Lithuanian 7 } \\
\text { Local Polish 5 }\end{array}$ & $\begin{array}{c}\text { Dialectal Lithuanian 7 } \\
\text { Local Polish 2 }\end{array}$ \\
\hline With strangers & $\begin{array}{c}\text { Dialectal Lithuanian 6 } \\
\text { Standard Lithuanian 2 }\end{array}$ & $\begin{array}{l}\text { Dialectal Lithuanian 6 } \\
\text { Standard Lithuanian 1 }\end{array}$ & $\begin{array}{c}\text { Dialectal Lithuanian 4 } \\
\text { Standard Lithuanian 4 }\end{array}$ \\
\hline With neighbours & $\begin{array}{c}\text { Dialectal Lithuanian 6 } \\
\text { Local Polish 6 }\end{array}$ & $\begin{array}{l}\text { Dialectal Lithuanian 7 } \\
\text { Local Polish 4 }\end{array}$ & $\begin{array}{l}\text { Dialectal Lithuanian 5 } \\
\text { Standard Lithuanian 5 }\end{array}$ \\
\hline Religious language & $\begin{array}{c}\text { Dialectal Lithuanian 7 } \\
\text { Local Polish 5 }\end{array}$ & $\begin{array}{l}\text { Dialectal Lithuanian 5 } \\
\text { Standard Lithuanian 2 }\end{array}$ & $\begin{array}{l}\text { Standard Lithuanian 5 } \\
\text { Dialectal Lithuanian 2 }\end{array}$ \\
\hline
\end{tabular}

One may observe a shift in the choice of language variation, too: the informants from the oldest generation typically use the local Polish or Lithuanian variations, and the use of language variations by the middle age group tends to vary, with the dialectal and/or standard variation used in one case or another. The youngest group of respondents, in turn, tend to preserve the characteristics of the standard (that is, non-dialectal) language, which means that they try to avoid using dialect.

\section{Salient (non)dialectal phonetic features}

Historically, local Polish-speaking residents of the Kaunas-Jonava region lived amidst the Western Higher Lithuanian subdialects of the Kaunas or Šiauliai regions. It is a known fact that speakers of Higher Lithuanian keep the stressed diphthongs

4 In some cases, the indicated number of replies does not match the number of respondents as the replies usually had multiple options. 
ie, uo intact (cf. pien(a)s, duona). However, in the case of Western Higher Lithuanian speakers unchanged are also the former nasal vowels $q$, $e$ (cf. kasti, kęsti) and sequences an, en and am, em (kanda, penki, kampas, etc.). Speakers of Western Higher Lithuanian of the Kaunas region most probably distinguish the long and short vowels the best (cf. giria and gyré, buvo and bivva), and do not retract stress from the ending of the word (gyvà vištà). By contrast, speakers of Western Higher Lithuanian of the Šiauliai region tend to: (1) shorten non-stressed long vowels, making them short or semi-long (pronouncing givenimas instead of gyvenimas); (2) make stressed short vowels longer (ritas(i) sounds like rytas); and (3) retract stress from the ending of the word (pronouncing rankà as rañka), and so on (Girdenis \& Zinkevičius, 1966, pp. 139-147; Kazlauskaitè, Lapinskienė, \& Bacevičiūtė, 2007, pp. 25-28; Zinkevičius, 2002, pp. 366, 2006, pp. 203-205).

Based on these characteristics, it would be easy to identify the dialectal affinity of an informant living in a monolingual environment. Yet these characteristics are obviously not enough when it comes to a multilingual (and multi-dialectal) setting. People who speak the local variation of Polish can speak Lithuanian in a way that is slightly different from that of the users of the traditional local subdialects.

First of all, their speech is characterised by a more pronounced diphthongisation of the long stressed Lithuanian vowels $\dot{e}$ and $o$ : atbiega instead of atbega; turiejau instead of turejau; pradiejau instead of pradejjau; muotina instead of motina; nakvuodavom instead of nakvodavom; tuortu instead of tortu, and so on. A certain degree of non-distinction between $o$ and $u o$ even when they are in a stressed position is evident in cases such as arodo instead of aruodo, atvažioja instead of atvažiuoja, seso instead of sesuo, maišose instead of maišuose. It is these examples that testify that the diphthongisation of $\dot{e}$ and $o$ is not a very old phenomenon, nor is it typical of the local Lithuanian variation; that is most likely why it has been left outside the scope of critical twentieth-century Lithuanian papers on dialectology concerned with the Kaunas-Jonava region (Morkūnas, 1982, pp. 44-45, 53-54, maps no. 27, 35; Zinkevičius, 1966, pp. 71, 74, 473, 479).

As mentioned above, both speakers of the Šiauliai region subdialect and the residents who speak the local Polish language tend to retract stress from the ending of the word when they speak Lithuanian. In this regard, both local (Polish and Lithuanian) variations are comparable. After all, stressing the penultimate syllable is a typical feature of the Polish language as well.

A multilingual (or Polish-speaking) informant is easy to identify from the way they pronounce originally circumflexed diphthongs that contain a circumflex vowel $(a \tilde{\imath}, a \tilde{u}, e \tilde{\imath} ; a \tilde{l}, a \tilde{m}, a \tilde{n}, a \tilde{r} .$.$) , because it is the first rather than the second com-$ ponent of the diphthong that is accentuated: balsas 'bal̃sas', vargas 'var̃gas', ranka 'rañką, and so on. This shows that the typical intonation opposition of Lithuanian diphthongs (stressed acute : stressed circumflex) is abandoned in favour of a more 
simplified system of stressed : unstressed. This phenomenon has been observed in many peripheral areas of Baltic and Slavic languages (for more information, see Mikuleniené, 1993, 1996-1997; Микуленене, 1995).

Another feature that gives away the non-Lithuanian base of articulation is the pronunciation of the soft consonant $\hat{s}$ which sounds very much like the Polish pre-palatal ś. Notably, this transformation of articulatory characteristics is typical of Lithuanians living in Poland who have preserved Lithuanian subdialects (Mikulènienè et al., 2016, pp. 100-119; Niewulis-Grablunas, 2008, p. 146).

Due to historical reasons, the Lithuanian language used to be a backup option in the Žeimiai area, just as it was in the entire Kaunas-Jonava region. The locals would adapt to historical circumstances, learning and using the language that was economically stronger. However, when historical and sociocultural circumstances change and one local language variation begins to exert pressure on another, it is not only the weaker variation that falls under the influence of the stronger, but also vice-versa: the stronger variation is apt to absorb some of the local characteristics of the weaker one.

\section{Conclusions}

Evaluating the competitiveness of local language variants used in the Žeimiai area of the Kaunas-Jonava region in the early twenty-first century, it can be stated that the speakers have a choice of two (not three) variants: either local Polish and dialectal Lithuanian, or the local dialectal variant and standard (non-dialectal) Lithuanian.

It needs to be stressed that the local Lithuanian variation that has formed in the Kaunas-Jonava region on the basis of the local Polish variation, which has been in active use for decades, is not the same as the traditional Western Higher Lithuanian subdialects of the Kaunas or Šiauliai regions. What makes it different from the traditional Lithuanian subdialects is the mixing of $\dot{e}$ and $i e, o$ and $u o$ in stressed position, and the processes of neutralisation of intonation in stressed diphthongs.

The influence of the local Polish subdialect can still be identified in the Lithuanian speech of local residents, which has inherited some of the former's phonetical qualities. As our analysis shows, they are preserved in the language of all three generations to a greater or lesser extent.

These features absorbed from the local Polish subdialect prevent us from considering the local Lithuanian variation currently spoken in the Kaunas-Jonava region a direct continuation of the old traditional dialect. 


\section{Bibliography}

Čepaitienè, A. (2016). Vakarų aukštaičių kauniškių ir rytų aukštaičių panevėžiškių sociokultūriniai tinklai. Taikomoji kalbotyra, 2016(8), 136-159. Retrieved August 24, 2018, from https://mif.vu.lt/ojs/index.php/taikomoji-kalbotyra/article/view/95/86

Geržotaitė, L. (2012). Pietinès vakarų aukštaičių šiauliškių šnektos: Geolingvistinis aspektas ir jo interpretacijos. Acta Linguistica Lithuanica, 67, 156-174.

Geržotaitė, L. (2017). Geolingvistinis Babtų apylinkių šnektų tyrimas. In D. Šniukas (Ed.), Babtai (pp. 1290-1299). Vilnius: Všt “Versmès” leidykla. Retrieved from http://llt.lt/ pdf/babtai/LLT_Babtai_Gerzotaite_moksl_str_2016_11_04.pdf

Girdenis, A., \& Zinkevičius, Z. (1966). Dèl lietuvių kalbos tarmių klasifikacijos. Kalbotyra, $14,139-147$.

Inoue, F. (1997). Market value of languages in Japan. Japanese Linguistics, 1997(2(October)), 40-61. Retrieved August 24, 2018, from https://dictionary.sanseido-publ.co.jp/ affil/person/inoue_fumio/doc/E21.pdf

Karaś, H. (2002). Gwary polskie na Kowieńszczyźnie. Warszawa: Wydawnictwo Aušra.

Kazlauskaitė, R., Lapinskienè, L., \& Bacevičiūtė, R. (2007). Vakaru aukštaičiai šiauliškiai. Vilnius: Lietuvių kalbos instituto leidykla.

Kviklys, B. (1991). Mūsu Lietuva. Vilnius: Mintis.

Leskauskaitè, A. (2016). Bendruomenès veiksnys: Sociokultūrinių tinklų perspektyva. In D. Mikulènienè, A. Leskauskaitè, V. Ragaišienè, L. Geržotaitè, \& N. Birgelienè, Lietuviu tarmiu kaita XXI a. pradžioje: Lenkijos lietuvių šnektos (pp. 276-300). Vilnius: Lietuvių kalbos institutas.

Mikulènienè, D. (1993). Priegaidžių defonologizacijos tendencijos Gervèčių tarmèje. Lietuvių kalbotyros klausimai, 30, 95-104.

Mikulènienè, D. (1996-1997). Einwirkung der slawischen Sprachen auf die Lautstruktur der peripheren litauischen Mundarten. Linguistica Baltica, 5-6, 57-67.

Mikulėnienė, D., Leskauskaitė, A., Ragaišienė, V., Geržotaitė, L., \& Birgelienė, N. (2016). Lietuviu tarmiu kaita XXI a. pradžioje: Lenkijos lietuvių šnektos: Kolektyviné monografija. Vilnius: Lietuvių kalbos institutas.

Mikulënienè, D., \& Meiliūnaitè, V. (Eds.). (2014). XXI a. pradžios lietuviu tarmès: Geolingvistinis ir sociolingvistinis tyrimas: Žemèlapiai ir ju komentarai. Vilnius: Lietuvių kalbos institutas, Leidykla Briedis.

Mikulėnienè, D., \& Rutkowska, K. (2013). Współczesna sytuacja językowa na Litwie: Aspekt geolingwistyczny i nowe możliwości opisu. Acta Baltico-Slavica, 37, 459-471. https:// doi.org/10.11649/abs.2013.031

Morkūnas, K. (Ed.). (1982). Lietuviu kalbos atlasas: Vol. 2. Fonetika. Vilnius: Mokslas.

Niewulis-Grablunas, J. (2008). Punsko šnektos pagrindinių fonetinių procesų apžvalga. In J. Niewulis-Grablunas, J. Prusinowska, \& E. Stryczyńska-Hodyl (Eds.), Perspectives of Baltic philology (pp. 139-146). Poznań: Wydawnictwo Rys. 
Pacevičiūtè, A. (2018). Kalbų rinka: Vietiniu varianty konkurencingumas Žeimiu apylinkèse (Jonavos rajono sav.) (Master's thesis). Vilniaus universitetas, Kauno fakultetas, Kalbų, literatūros ir vertimo studijų institutas, Kaunas.

Rutkovska, K. (2014). Lenkų kalbos paplitimas ir vartojimo ypatumai. In D. Mikulènienè \& V. Meiliūnaitè (Eds.), XXI a. pradžios lietuviu tarmès: Geolingvistinis ir sociolingvistinis tyrimas: Žemélapiai ir ju komentarai (pp. 216-227). Vilnius: Lietuvių kalbos institutas, Leidykla Briedis.

Williams, G. (2005). Sustaining language diversity in Europe: Evidence from the Euro-mosaic Project. Basingstoke: Palgrave Macmillan. https://doi.org/10.1057/9780230514683

Zielińska, A. (2002). Polska mniejszość na Litwie Kowieńskiej: Studium socjolingwistyczne. Warszawa: Slawistyczny Ośrodek Wydawniczy.

Zinkevičius, Z. (1966). Lietuviu dialektologija. Vilnius: Mintis.

Zinkevičius, Z. (2002). Apie lietuvių kalbos tarmių skirstymą. In Z. Zinkevičius, Rinktiniai straipsniai 1 (pp. 365-380). Vilnius: Kataliku akademija.

Zinkevičius, Z. (2006). Lietuviu tarmiu kilmè. Vilnius: Lietuvių kalbos instituto leidykla.

Микуленене, Д. (1995). Нейтрализация оппозиции слоговых интонаций литовского языка в говорах балто-славянского пограничья. In M. Kondratiuk (Ed.), Badania dialektów i onomastyki na pograniczu polsko-wschodniosłowiańskim (pp. 181-186). Białystok: Uniwersytet Warszawski, Filia w Białymstoku.

\section{Bibliography (Transliteration)}

Čepaitienè, A. (2016). Vakarų aukštaičių kauniškių ir rytų aukštaičių panevėžiškių sociokultūriniai tinklai. Taikomoji kalbotyra, 2016(8), 136-159. Retrieved August 24, 2018, from https://mif.vu.lt/ojs/index.php/taikomoji-kalbotyra/article/view/95/86

Geržotaite, L. (2012). Pietinès vakarų aukštaičių šiauliškių šnektos: Geolingvistinis aspektas ir jo interpretacijos. Acta Linguistica Lithuanica, 67, 156-174.

Geržotaite, L. (2017). Geolingvistinis Babtų apylinkių šnektų tyrimas. In D. Šniukas (Ed.), Babtai (pp. 1290-1299). Vilnius: Všt “Versmès” leidykla. Retrieved from http://llt.lt/ pdf/babtai/LLT_Babtai_Gerzotaite_moksl_str_2016_11_04.pdf

Girdenis, A., \& Zinkevičius, Z. (1966). Dèl lietuvių kalbos tarmių klasifikacijos. Kalbotyra, 14, 139-147.

Inoue, F. (1997). Market value of languages in Japan. Japanese Linguistics, 1997(2(October)), 40-61. Retrieved August 24, 2018, from https://dictionary.sanseido-publ.co.jp/ affil/person/inoue_fumio/doc/E21.pdf

Karaś, H. (2002). Gwary polskie na Kowieńszczyźnie. Warszawa: Wydawnictwo Aušra.

Kazlauskaite, R., Lapinskienè, L., \& Bacevičiūtè, R. (2007). Vakaru aukštaičiai šiauliškiai. Vilnius: Lietuvių kalbos instituto leidykla.

Kviklys, B. (1991). Mūsų Lietuva. Vilnius: Mintis. 
Leskauskaitė, A. (2016). Bendruomenès veiksnys: Sociokultūrinių tinklų perspektyva. In D. Mikulènienè, A. Leskauskaitè, V. Ragaišienè, L. Geržotaitè, \& N. Birgelienè, Lietuviu tarmiu kaita XXI a. pradžioje: Lenkijos lietuvių šnektos (pp. 276-300). Vilnius: Lietuvių kalbos institutas.

Mikulènienè, D. (1993). Priegaidžių defonologizacijos tendencijos Gervèčių tarmèje. Lietuviu kalbotyros klausimai, 30, 95-104.

Mikulenene, D. (1995). Neĭtralizatsiia oppozitsii slogovykh intonatsiŭ litovskogo iazyka v govorakh balto-slavianskogo pogranich'ia. In M. Kondratiuk (Ed.), Badania dialektów i onomastyki na pograniczu polsko-wschodniosłowiańskim (pp. 181-186). Białystok: Uniwersytet Warszawski, Filia w Białymstoku.

Mikulènienè, D. (1996-1997). Einwirkung der slawischen Sprachen auf die Lautstruktur der peripheren litauischen Mundarten. Linguistica Baltica, 5-6, 57-67.

Mikulènienè, D., Leskauskaitė, A., Ragaišienè, V., Geržotaitė, L., \& Birgelienė, N. (2016). Lietuvių tarmiu kaita XXI a. pradžioje: Lenkijos lietuvių šnektos: Kolektyvinè monografija. Vilnius: Lietuvių kalbos institutas.

Mikulënienè, D., \& Meiliūnaitè, V. (Eds.). (2014). XXI a. pradžios lietuviu tarmès: Geolingvistinis ir sociolingvistinis tyrimas: Žemélapiai ir ju komentarai. Vilnius: Lietuvių kalbos institutas, Leidykla Briedis.

Mikulènienė, D., \& Rutkowska, K. (2013). Współczesna sytuacja językowa na Litwie: Aspekt geolingwistyczny i nowe możliwości opisu. Acta Baltico-Slavica, 37, 459-471. https:// doi.org/10.11649/abs.2013.031

Morkūnas, K. (Ed.). (1982). Lietuvių kalbos atlasas: Vol. 2. Fonetika. Vilnius: Mokslas.

Niewulis-Grablunas, J. (2008). Punsko šnektos pagrindinių fonetinių procesų apžvalga. In J. Niewulis-Grablunas, J. Prusinowska, \& E. Stryczyńska-Hodyl (Eds.), Perspectives of Baltic philology (pp. 139-146). Poznań: Wydawnictwo Rys.

Pacevičiūtè, A. (2018). Kalbų rinka: Vietiniu variantų konkurencingumas Žeimiu apylinkèse (Jonavos rajono sav.) (Master's thesis). Vilniaus universitetas, Kauno fakultetas, Kalbų, literatūros ir vertimo studijų institutas, Kaunas.

Rutkovska, K. (2014). Lenkų kalbos paplitimas ir vartojimo ypatumai. In D. Mikulènienè \& V. Meiliūnaitè (Eds.), XXI a. pradžios lietuviu tarmès: Geolingvistinis ir sociolingvistinis tyrimas: Žemélapiai ir ju komentarai (pp. 216-227). Vilnius: Lietuvių kalbos institutas, Leidykla Briedis.

Williams, G. (2005). Sustaining language diversity in Europe: Evidence from the Euro-mosaic Project. Basingstoke: Palgrave Macmillan. https://doi.org/10.1057/9780230514683

Zielińska, A. (2002). Polska mniejszość na Litwie Kowieńskiej: Studium socjolingwistyczne. Warszawa: Slawistyczny Ośrodek Wydawniczy.

Zinkevičius, Z. (1966). Lietuviu dialektologija. Vilnius: Mintis.

Zinkevičius, Z. (2002). Apie lietuvių kalbos tarmių skirstymą. In Z. Zinkevičius, Rinktiniai straipsniai 1 (pp. 365-380). Vilnius: Katalikų akademija.

Zinkevičius, Z. (2006). Lietuviu tarmiu kilmè. Vilnius: Lietuvių kalbos instituto leidykla. 


\title{
Language shift: The case of the Žeimiai area in the Kaunas-Jonava region
}

\begin{abstract}
As a result of application of the principles of multidimensional dialectology in Lithuania in the early twenty-first century, the research discourse of Lithuanian dialectologists now covers not only the traditional dialects, but also several local language variations that continuously interact and compete with one another in the same geographical area. The processes of convergence and divergence of language variations are addressed in a more comprehensive manner, not only analysing the linguistic characteristics of a local variation, but also looking into the language environment (or language landscape) and the attitude of the local populace (especially the young generation) towards their linguistic homeland.

The linguistic study presented in this article was conducted in the Žeimiai area in the Kaunas-Jonava region in 2015-2017. It involved interviews with 21 members of three generations of one family (15 females and 6 males aged 19 to 95), over 20 hours of audio material in total; the informants also answered a sociolinguistic survey. The description and analysis of collected material involved: (1) analysis of the degree of viability of language variations used in the area on the basis of a model of sociocultural networks of Žeimiai town; (2) description of the linguistic landscape of the region; (3) description of the linguistic behaviour and attitudes towards local variations on the basis of informants' replies in the sociolinguistic survey; (4) analysis of salient phonetic features of the informants' speech that best describe the local language variation in use. The collected and processed material allowed the researchers to investigate the competitiveness of local language variations in this area, identifying ones that have greater demand with representatives of different generations compared to others (cf. Inoue, 1997, p. 41).

In the opinion of the authors of this article, a local Lithuanian variation has developed in the Kaunas-Jonava region on the basis of the local Polish variation actively used for decades; this variation cannot be seen as a natural continuation of the Western Higher Lithuanian subdialects of the Kaunas or Šiauliai regions. What makes it different from the traditional Lithuanian subdialects is the mixing of $\dot{e}$ and $i e, o$ and $u o$ in stressed position, and the processes of neutralisation of intonation in stressed compound and mixed diphthongs.

These phonetic features, which, as the analysis shows, have been preserved in the language of all three generations to a greater or lesser extent, were absorbed by the Lithuanian dialectal language from the local Polish subdialect. Consequently, the local Lithuanian variation currently spoken in the Kaunas-Jonava region cannot be considered a direct continuation of the old traditional dialect.
\end{abstract}


Keywords: multimodal dialectology; local dialects of Lithuanian; local dialects of Polish; convergence

\section{Przesunięcie językowe: Okolice Żejm w regionie kowieńsko-janowskim (studium przypadku)}

\section{Streszczenie}

Kiedy na początku XXI wieku na Litwie zaczęto stosować metodologię opartą na zasadach dialektologii wielofunkcyjnej (ang. multidimensional dialectology), badania naukowe litewskich dialektologów ukierunkowano nie tylko na opis tradycyjnych gwar, ale też na inne języki współwystępujące na tym samym terenie, oddziałujące na siebie nawzajem i konkurujące ze sobą. Zachodzące procesy konwergencji i dywergencji różnych odmian języka są badane kompleksowo: przy opisie właściwości językowych miejscowej odmiany języka bada się otoczenie językowe (krajobraz lingwistyczny) oraz nastawienie mieszkańców (zwłaszcza najmłodszego pokolenia) do ukształtowanej sytuacji językowej.

Badania językoznawcze przedstawione $\mathrm{w}$ niniejszym artykule przeprowadzono w okolicach Żejm w regionie kowieńsko-janowskim w latach 2015-2017. Przeprowadzono wywiady z 21 mieszkańcami w wieku od 19 do 95 lat, reprezentującymi trzy pokolenia jednej rodziny; nagrano 20 godzin rozmów i pozyskano dane za pomocą kwestionariusza socjolingwistycznego. Zgromadzony materiał został opracowany w następujący sposób: 1) wykorzystując sporządzony model sieci społeczno-kulturowych miasteczka Żejmy, ustalono stopień witalności używanych na tym terenie odmian języka; 2) zanalizowano krajobraz lingwistyczny regionu; 3) na podstawie odpowiedzi informatorów na pytania kwestionariusza socjolingwistycznego przedstawiono zachowania językowe osób badanych i ich nastawienie do lokalnych odmian języka; 4) dokonano analizy podstawowych cech fonetycznych języka respondentów, które najlepiej oddają właściwości miejscowych odmian języka. Zgromadzony i usystematyzowany materiał pozwolił na bardziej dogłębne zbadanie konkurencyjności odmian języka używanych w tym rejonie, to znaczy na ustalenie, która $\mathrm{z}$ odmian cieszy się wyższym prestiżem wśród reprezentantów różnych pokoleń mieszkańców tych okolic.

Zdaniem autorek artykułu, w regionie kowieńsko-janowskim, pod wpływem miejscowej odmiany języka polskiego, intensywnie używanej przez wiele dziesięcioleci, ukształtował się lokalny wariant języka litewskiego, którego nie można uznać za typową gwarę dialektu zachodnioauksztockiego, kowieńskiego lub szawelskiego. Różni się on od tradycyjnych dialektów litewskich sposobem realizacji 
$\dot{e}$ oraz $i e, o$ oraz $u o$ w pozycji akcentowanej, jak również zjawiskiem neutralizacji zestrojów akcentowych w dyftongach złożonych i mieszanych, występujących w pozycji akcentowanej.

Te cechy fonetyczne, które, jak wynika z przeprowadzonej analizy, w różnym stopniu występują $\mathrm{w}$ języku wszystkich trzech pokoleń mieszkańców, zostały przejęte do języka litewskiego z miejscowej gwary polskiej. Dlatego nie można uznać lokalnej odmiany języka litewskiego używanej obecnie w regionie kowieńsko-janowskim za bezpośrednią kontynuację dawnego tradycyjnego dialektu litewskiego.

Słowa kluczowe: dialektologia multimodalna; gwary litewskie; gwary polskie; konwergencja

Dr hab. Danguolè Mikulènienè is Head of the Centre of Geolinguistics and Chief Researcher at the Institute of the Lithuanian Language. PhD thesis - 1987, Vilnius University; habilitation procedure - 2007, Vytautas Magnus University, Kaunas. Since 2010 she has been Professor at the Institute of Language, Literature and Translation Studies at the Kaunas Faculty of Vilnius University. Her main interest lies in the fields of diachronic and synchronic dialectology, geolinguistics, accentuation and morphonology, history of language, Lithuanian language standardisation and teaching. She is the editor and author of eight collective monographs, six dialectal dictionaries and other dialectal sources, and over thirty handbooks and teaching aids. She has authored two monographs and published approximately sixty scholarly articles.

Bibliography (selected): Cirkumfleksinè metatonija vardažodiniuose daiktavardžiuose ir jos kilmé [Circumflex metatony in nominal nouns and its origins], Vilnius 2005; Lietuviu tarmètyra: genezè, raida ir paradigminiai lüžiai. D. 1 [Lithuanian dialectology: Genesis, development and paradigmatic breakthroughs. Part 1], Vilnius 2018. Co-author: Baltu valodu atlants - Baltu kalbu atlasas - Atlas of the Baltic languages, Riga and Vilnius 2009, Vilnius 2013; XXI a. pradžios lietuviu tarmés: geolingvistinis ir sociolingvistinis tyrimas. Žemelapiai ir ju komentarai [Modern geolinguistic research in Lithuania: The optimisation of network points and the interactive dissemination of information], Vilnius 2014; Kalbos variantiškumas ir jo vertinimas perceptyviosios dialektologijos požiūriu: variantu ir vietu vaizdiniai [Language variation and its evaluation from the perspective of perceptual dialectology: Images of variants and locations], Vilnius 2017. 
Aušra Pacevičiūtė, Master of Linguistics. Master's thesis - 2018, University of Vilnius. Scholarly interests: dialectology, local dialects, regional variants, social linguistics.

Correspondence: Danguolè Mikulènienè, Institute of the Lithuanian Language, Vilnius, Lithuania, e-mail: Iki@Iki.lt; Aušra Pacevičiūtė, Kaunas Faculty of Vilnius University, Kaunas, Lithuania, e-mail: info@knf.vu.It

Support of the work: This work was supported by core funding for the statutory activity of the Institute of the Lithuanian Language and Vilnius University.

Authors' contribution: The first author, DM, is responsible for the concept of the study; the second author, AP, collected and analysed the data. Both authors participated in drafting the manuscript.

Competing interests: DM is a member of the Scientific Board of this journal. AP declares that she has no competing interests. 